\title{
Determinant Factors of Jakarta Composite Index
}

\author{
Dwi Rahmalia dan Augustina Kurniasih
}

\section{ABSTRACT}

\begin{abstract}
This study aims to examine empirically the influence of macroeconomic variables, namely: GDP growth, inflation, Rupiah exchange rates, and interest rates on the JCI on the Indonesia Stock Exchange. The analysis technique used is multiple regression. The results of the study found that only GDP growth and exchange rates had a significant effect on the JCI, while the inflation rate and interest rates had no effect on the JCI. This study only uses four macroeconomic variables, so further research needs to find other macroeconomic variables that are thought to have an effect on the JCI.
\end{abstract}

Keywords: Macroeconomic Variables, GDP Growth, Inflation, Rupiah Exchange Rate, Interest Rates, JCI.

\section{INTRODUCTION}

Jakarta Composite Index (JCI) is used to determine the conditions of activity in the capital market. The increasing JCI indicates an increase in transactions in the capital market, and vice versa. Tandelilin [1] argues that the JCI is a benchmark for investors in the capital market so that various factors that influence it are of further attention.

Sihombing [2] states that macroeconomic conditions affect the volatility of the JCI. Specifically, Sihombing [2] explains that the macroeconomic environment can directly affect company performance and stock performance including GDP, inflation, Rupiah exchange rate, and interest rates.

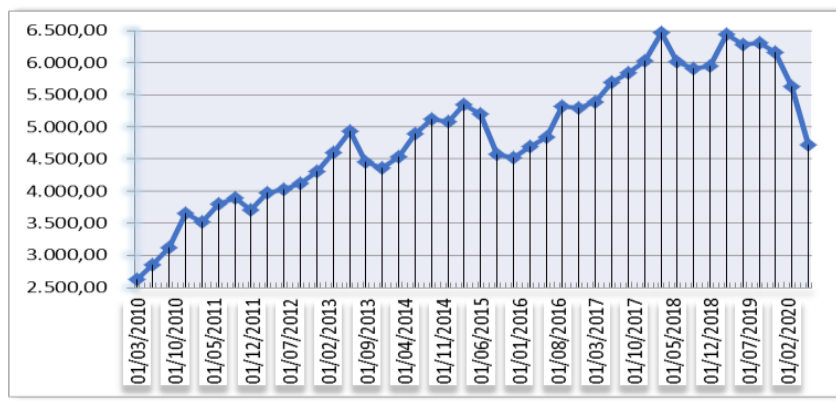

Fig. 1. Development of the average JCI value. Source: Bloomberg, data processed (2020).

The development of the JCI during the first quarter of 2010 to the second quarter of 2020 was quite volatile from the lowest value of 2,623.73 in the first quarter of 2010 and the highest value of 6,464.78 in the first quarter of 2018 .

In the second quarter of 2020, the JCI fell significantly by

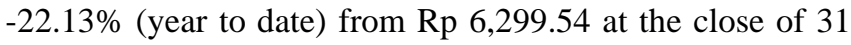
December 2019 to Rp 4,905.39 on 30 June 2020. The declining JCI shows the capital market as a barometer the economy is in a slump. Therefore, it is necessary to analyse what macroeconomic factors influence the JCI, making it easier for investors to make investment decisions.

\author{
Submitted : February 15, 2021 \\ Published : March 9, 2021 \\ ISSN: 2507-1076 \\ DOI: $10.24018 /$ ejbmr.2021.6.2.755
}

Dwi Rahmalia dan Augustina Kurniasih*

Universitas Mercu Buana Jakarta, Indonesia.

(e-mail: dwirahmalia.dr@gmail.com)

*Corresponding Author
Several previous studies have been carried out in looking for the factors that influence the JCI. The results of Wijayanti's research [3] state that GDP does not have a significant effect on the JCI both in the short and long term. Similar to Kewal [4] who also found that GDP had no significant effect on the JCI. In contrast to the above studies, research conducted by Husnul et al. [5] actually obtained results that show that GDP has a significant positive effect on the JCI.

The empirical study of the effect of interest rates on the JCI from Kewal [4] and Wijayanti [3] shows that interest rates do not have a significant effect on the JCI. In contrast to Mamahit et al. [6] who found that interest rates have a negative and significant effect on the JCI.

Research results from Kewal [4] and Sihombing et al. [2] found that the rupiah exchange rate had a negative effect on the JCI. Different results were found by Salim et al. [7] that the Exchange Rate / US \$ has a positive and significant effect on Jakarta Composite Index (JCI). The positive effect of the rupiah exchange rate variable on the JCI shows that the strengthening of the US dollar exchange rate (the depreciating rupiah) will actually increase thx JCI.

Research conducted by Kewal [4] and Wijayanti [3] shows that inflation has no significant effect on the JCI. However, Triyono et al. [8] stated that inflation negatively affected the JCI movement. In contrast to the research results of Astuti et al. [9] who found that inflation has a significant positive effect on the stock price index on the Indonesia Stock Exchange.

This study aims to re-examine the effect of macroeconomic variables, namely GDP growth, inflation, Rupiah exchange rates and interest rates on the JCI in the Indonesia Stock Exchange.

\section{LiterATURE REVIEW}

Signal theory [10] explains that management as an insider plays a role as a party that provides signals tox outsiders, such 
as investors. Spence said that by giving a signal or signal, management tries to provide relevant information that can be used by investors. Then, the investor will adjust his decision according to his understanding of the signal.

According to Brigham and Houston [11] a signal is an action taken by a company to provide guidance to investors on how management views the company's prospects. Signal theory shows the existence of asymmetric information between company management and parties with an interest in the information. This signal is in the form of information about what management has done to realize the owner's wishes. When the information is announced and all market participants have received the information, market players will first interpret and analyze the information as a good signal (good news) or a bad signal (bad news). If this information is a good signal for investors, there will be changes in the price and trading volume of shares.

Bodie et al. [12] defines investment as a commitment to a number of funds or other resources that are carried out at this time with the aim of obtaining profits in the future. Investment is the delay in current consumption for use in efficient production over a specified period of time. According to Bodie et al. [12] there are two forms of investment, namely financial assets and real assets.

Financial assets are assets that are invisible but have a high value. Investments in financial assets can be made in the capital market. The capital market in Indonesia is the Indonesia Stock Exchange (BEI). Indicators of activity on the IDX can be seen from the Jakarta Composite Index (JCI).

JCI is a series of information regarding the movement of joint stock prices. The movement of joint stock prices is presented every day based on the closing price on the stock exchange on that day. The JCI calculation uses all shares listed on the stock exchange. To that end, the JCI reflects the development of the stock market as a whole [13].

Gross Domestic Product (GDP) is an indicator of economic growth in a country. Tandelilin [1] argues that an increase in GDP will increase people's purchasing power so that it can directly increase company sales and significantly increase the JCI condition.

Inflation will cause an increase in company costs and revenues. If the price increase enjoyed by the company is lower than the increase in production costs, the company's profit will decrease. A decrease ain company profits will cause the company's stock price to fall [1]. When many stock prices have decreased, the JCI will weaken.

The rupiah exchange rate is a comparison of the value of the rupiah currency with the currency of other countries. If the rupiah exchange rate is formulated against the dollar, it means that the rupiah is needed to buy one dollar [1]. If the rupiah exchange rate increases, it means that the rupiah is depreciating (weakening), while if the rupiah exchange rate decreases, it means that the rupiah has appreciated (strengthened).

High bank interest rates are a consideration for investors to move investment from stocks to savings or deposits because they have a lower risk [1]. If many investors withdraw their funds in stocks and move them to the money market, it will make the stock price fall. When many stock prices fall, it will cause the JCI to weaken.

Based on the literature above, a research framework is prepared that shows the relationship between variables.

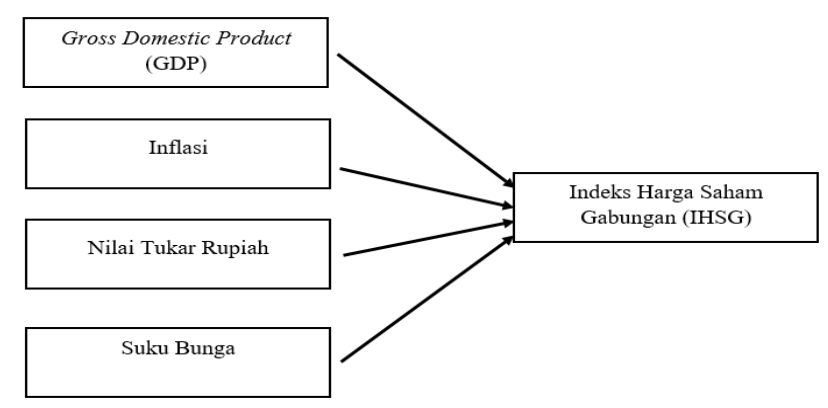

Fig. 2. Framework.

\section{RESEARCH METHODOLOGY}

This research is a causality research which aims to explain the causal relationship between research variables through hypothesis testing. The research population is the Jakarta Composite Index (JCI). The research sample was JCI in the period of the 1 st quarter of 2010 to the 2 nd quarter of 2020 or as many as 42 observation data.

The research data is secondary data and is time-series in nature, which is a ratio scale data. The operational definitions of the research variables are presented in Table1.

\begin{tabular}{cccc}
\multicolumn{4}{c}{ TABLE1: OPERATIONAL DEFINITION AND VARIABLE MEASUREMENT } \\
\hline No & Variable & Measurement & Source \\
\hline 1. & $\begin{array}{c}\text { Jakarta Composite } \\
\text { Index }(\mathrm{JCI})(\mathrm{Y})\end{array}$ & JCI average value & bloomberg \\
2 & $\begin{array}{c}\text { Gross Domestic } \\
\text { Product }(\mathrm{GDP})\left(\mathrm{X}_{1}\right)\end{array}$ & $\begin{array}{c}\text { GDP value } \\
\text { consumer price } \\
\text { index } \\
\text { Inflation }\left(\mathrm{X}_{2}\right)\end{array}$ & bps.go.id \\
& biddle rate & \\
& Exchange rate $\left(\mathrm{X}_{3}\right)$ & $\begin{array}{c}\text { Rupiah exchange } \\
\text { rate against US } \\
\text { dollar }\end{array}$ & bi.go.id \\
& & $\begin{array}{c}\text { The reference } \\
\text { interest rate set by } \\
\text { Bank Indonesia. }\end{array}$ & bi.go.id \\
\hline
\end{tabular}

Analysis of the data used to find the effect of the independent variables on the dependent variable using a multiple linear regression approach. The regression equation proposed is:

$$
Y t=a+b 1 X 1 t+b 2 X 2 t+b 3 X 3 t+b 4 X 4 t+e
$$

where

Y : Jakarta Composite Index,

a : Constants,

$\mathrm{b}:(\mathrm{b} 1, \mathrm{~b} 2, \mathrm{~b} 3, \mathrm{~b} 4)$ the regression coefficient,

$\mathrm{X} 1$ : GDP,

$\mathrm{X} 2$ : Inflation,

X3 : The Exchange Rate of the Rupiah against the US Dollar, X4 : Interest Rate,

e : Error.

\section{RESUlT AND DISCUSSION}

Descriptive statistics on the research variables are presented in Table 2. It can be seen that the lowest JCI was $2,623.73$ occurred in the 1 st quarter of 2010 and the highest value of $6,464.78$ occurred in the 1 st quarter of 2018 . In the 
1st quarter of 2010, Asian exchanges fluctuated quite a bit and the rupiah exchange rate weakened (exchange rate depreciation), thus causing the JCI to be prone to correction. Meanwhile, the highest JCI occurred in the first quarter of 2018, which is suspected of increasing Indonesia's GDP and also improving the rupiah exchanger rate (exchange rate appreciation).

TABLE 2: DESCRIPTIVE STATISTICS OF RESEARCH VARIABLES

\begin{tabular}{ccccc}
\multicolumn{4}{c}{ TABLE 2: DESCRIPTIVE STATISTICS OF RESEARCH VARIABLES } \\
\hline & Minimum & Maximum & Mean & $\begin{array}{c}\text { Std. } \\
\text { Deviation }\end{array}$ \\
\hline Gross Domestic & $-5,32$ & 6,76 & 5,12 & 1,78 \\
Product (GDP) & 1,96 & 8,36 & 4,58 & 1,74 \\
Inflation & $8.597,00$ & $16.367,01$ & $12.067,62$ & $2.238,37$ \\
Exchange Rate & 4,25 & 7,75 & 6,05 & 1,09 \\
Interest Rate & $2.623,73$ & $6.464,78$ & $4.859,58$ & $1.002,89$ \\
Jakarta Composite & & & & \\
Index (JCI) & & & &
\end{tabular}

Gross Domestic Product (GDP) has the lowest (minimum) value of -5.32 occurring in the second quarter of 2020, which indicates that Indonesia's economy has contracted or negative by $5.32 \%$ year on year or compared to the same period last year. The corona virus pandemic that has occurred has hit all aspects of human life, including the economic sector. Largescale social restrictions (PSBB) carried out by a number of regions prevented the economy from rotating normally. The factories did not operate, there were layoffs (PHK), many people had to lose their income, causing a negative GDP value of $5.32 \%$. The highest Gross Domestic Product (GDP) value (maximum) of 6.76 occurred in the second quarter of 2010 , indicating that the Indonesian economy is improving, as reflected in the balance of payments which is experiencing a fairly large surplus and improving performance in the financial sector.

Inflation has the lowest (minimum) value of 1.96 occurring in the second quarter of 2020, this is due to slower production and consumption activities due to ethe implementation of large-scale social restrictions (PSBB). The highest inflation value (maximum) of 8.36 occurred in the fourth quarter of 2014 due to the increase in subsidized fuel prices which caused raw material prices to increase so that inflation rose to $8.36 \%$ at the end of 2014 .

The rupiah exchange rate has the lowest (minimum) value of 8,597.00 occurred in the second quarter of 2011, this is because Indonesia recorded a trade surplus against the United States, so the demand for rupiah was higher than the demand for dollars. As a result, the purchasing power of the rupiah against the US dollar has strengthened (appreciation). The highest rupiah exchange rate (maximum) of 16,367.01 occurred in the first quarter of 2020. One of the factors causing the depreciation of the rupiah was the decline in production activities due to social restriction policies. The decline in production activities causes a decrease in the income of companies that are the driving force of the economy. This pandemic caused the rupiah to be shaken and depreciated considerably. As a result, the rupiah's weakest point in 1998 was successfully breached in March 2020 [14].

The interest rate has the lowest (minimum) value of 4.25 occurring in the third quarter of 2017 to the first quarter of 2018. The Meeting of the Board of Governors (RDG) of Bank Indonesia (BI) decided to lower the benchmark interest rate in the 3rd quarter of 2017 due to 4 In this regard, inflation until mid-2017 was lower than the Government's estimate, the current account deficit (CAD) remained under control, eased external risk factors, and lower reference interest rates were expected to boost bank lending while supporting sustainable economic growth (Bank Indonesia 2017). The highest interest rate (maximum) of 7.75 occurred in the fourth quarter of 2014 , this was due to the high uncertainty of global financial markets (Bank Indonesia 2014).

TABLE 3: RESULTS OF MULTIPLE LINEAR REGRESSION ANALYSIS

\begin{tabular}{ccccc}
\hline & B & Std. Error & t & Sig. \\
\hline (Constant) & 112,623 & 41,049 & 2,744 & 0,009 \\
Gross Domestic & 160,591 & 31,176 & 5,151 & 0,000 \\
Product (GDP) & & 33,762 & 0,325 & 0,747 \\
Inflation & 10,985 & 0,063 & $-2,906$ & 0,006 \\
Exchange Rate & $-0,183$ & 0,061 & $-1,310$ & 0,198 \\
Interest Rate & $-120,904$ & 92,291 & $\mathbf{0 , 4 5 5}$ & \\
R $^{2}$ & & $\mathbf{0 , 3 9 4}$ & \\
Adj-R $^{2}$ & & $\mathbf{7 , 5 1 1}$ & \\
F-statistic & & $\mathbf{0 , 0 0 0}$ & \\
Prob(F-statistic) & &
\end{tabular}

Table 3 presents the test results of the regression model regarding the effect of Gross Domestic Product (GDP), Inflation, Rupiah Exchange Rate, Interest Rates on the JCI for the period of 1 st quarter 2010 to 2 nd quarter of 2020 . Based on Table- 3 the resulting regression equation is

$$
\begin{gathered}
Y=112,623+160,591 X_{1} t+10,985 X_{2} t-0,183 X_{3} t- \\
120,904 X_{4} t
\end{gathered}
$$

The constant value is 112.623 with a significance of 0.009 . Mean significant constant. If the independent variable Gross Domestic Product (GDP), Inflation, Exchange Rate, and Interest Rate is 0 , then the JCI has a value of 112,623.

The regression coefficient value of the Gross Domestic Product (GDP) variable (X1) is 160.591 with a significance of 0.000 . It means that GDP has a positive and significant effect. Every 1 unit increase in Gross Domestic Product (GDP) will increase the Jakarta Composite Index (JCI) by 160,591. This shows that the Gross Domestic Product (GDP) variable has a positive effect on the JCI.

The regression coefficient value of the inflation variable (X2) is 10.985 with a significance of 0.747 . This means that inflation has no significant effect on the JCI.

The regression coefficient value of the Rupiah Exchange Rate (X3) variable is -0.183 with a significance of 0.006 . This means that the rupiah exchange rate has a negative and significant effect on the JCI. Every increase in the Rupiah Exchange Rate by 1 unit, it will reduce the JCI by -0.183 , ceteris paribus.

The regression coefficient value of the Interest Rate variable (X4) is -120.904 with a significance of 0.198 . This means that interest rates have no significant effect on the JCI.

An increase in the Gross Domestic Product (GDP) in a country indicates an increase in the welfare of the people in that country. An increase in public welfare will encourage people to consume goods and services, this will have a positive impact on company performance, including companies listed on the IDX so that it will be reflected in the increase in share prices on the Indonesia Stock Exchange. An increasingly prosperous society will also have many investment opportunities, including investment in the capital 
market. If people invest a lot in the capital market, the stock price will increase. The increase in the prices of various shares will cause the JCI to increase. The results of this study support the research of Husnul et al. [5], Febrina et al. [15], Hsing [16], Singh et al. [17], Hunjra et al. [18], Chittedi [19], Jareno \& Negrut [20], and Pooja [21] who obtained GDP results had a significant positive effect on cthe Composite Index. This study is not in cline with Kewal's [4] research which shows that GDP does not have a significant effect on the JCI.

The test results show that partial inflation has no effect on the JCI. As presented in the descriptive statistics during the study period, namely the first quarter of 2010 to the second quarter of 2020, the inflation rate in Indonesia was always below $10 \%$ per year. Inflation of less than $10 \%$ can still be accepted by the market because the inflation rate is still in the creeping or low category. As a result, the inflation rate does not affect the fluctuation of the JCI. If inflation exceeds the $10 \%$ mark, the capital market will be disrupted because Bank Indonesia will increase the BI rate which will result in investors tending to shift their funds from the capital market to the money market [22]. The results of this study are in line with the results xof research by Kewal [4], Sihombing et al. [2], Syarif et al. [23], and Husnul et al. [5], which found that the xinflation rate did not have a significant effect on the JCI. The results of this study xare not in line with the research results of Astuti et al. [9], Triyono et al. [8], and Febrina et al. [15], which state that inflation has a positive and significant effect on the Jakarta Composite Index (JCI) in Indonesia Stock Exchange (IDX).

The results showed that the Rupiah Exchange Rate against the US Dollar had a negative and significant effect on the JCI. This indicates that the relationship between the rupiah exchange rate and the stock price is opposite, meaning that the stronger the rupiah exchange rate against the US \$ (the rupiah appreciates), the higher the stock price. This finding is consistent with the theory, where the strengthening of the rupiah exchange rate against the US $\$$ is a positive signal for the economy [1]. The strengthening of the rupiah exchange rate against the US \$ will reduce production costs, especially the cost of importing raw materials. The reduction in production costs will have a positive impact on company performance. If the companies have a good performance, the public's interest in investing in stocks will increase. Increased investment interest causes share prices in the capital market to increase. The results of this study are in line with research by Kewal [4], Sihombing et al. [2], Syarif et al. [23], and Triyono et al. [8], who found the rupiah exchange rate had a negative effect on the JCI.

The interest rate variable has no effect on the JCI because the type of investor in Indonesia is an investor who likes to do short-term stock transactions (traders / speculators), so investors tend to take profit taking in the hope of obtaining a high enough capital gain in the capital market compared to investing. on securities. In addition, if stock issuers pay dividends that are high enough for their shareholders, this will also be a stimulus for investors to invest in stocks rather than securities on the money market. The results of this study are in line with the results of Kewal's research [4] which was conducted in the period 2000 to 2009 which states that investors in Indonesia are more interested in stocks that pay high dividends than put their money in deposit instruments that have high interest rates. so that the interest rate variable has no effect on the JCI. The results of this study are not in line with the research results of Astuti et al. [9], which state that interest rates have a significant negative effect on the JCI in the period 2006 to 2015 because interest rates that are too high will have an effect on the value of the company's cash flow so that investment in stocks aren't that attractive anymore.

\section{Closing}

The results show that GDP has a positive effect, and the Rupiah exchange rate has a negative effect on the JCI in the Indonesia Stock Exchange. Meanwhile, inflation and interest rates have no significant effect on the JCI in the Indonesia Stock Exchange.

Referring to the results of this study, investors who invest in stocks are advised to pay attention to the magnitude of macroeconomic factors, especially Gross Domestic Product (GDP) and the rupiah exchange rate. This is because these macroeconomic factors have a significant influence on the JCI.

The government as a policy maker should take into account the impact of the policies taken, especially those that can affect the Gross Domestic Product (GDP) and the rupiah exchange rate because the results of this study indicate that these two variables have a significant effect on the JCI.

It is suggested that further researchers can add external factors besides Indonesia's macroeconomic factors such as indexes of other countries, extend the research period to test whether the current research results can be confirmed by the results of research that use more data. Future research is recommended to use monthly data so that the number of observations will increase.

\section{REFERENCES}

[1] Tandelilin, Eduardus. 2010. Portofolio dan Investasi Teori dan Aplikasi. Edisi pertama. Yogyakarta : Kanisius.

[2] Pardomuan Sihombing dan Rizal. 2014. Pengaruh Indeks Saham Global Dan Kondisi Makro Indonesia Terhadap Indeks Harga Saham Gabungan Bursa Efek Indonesia. Media Ekonomi Vol. 22 No.2 Agustus 2014: 133-149.

[3] Wijayanti, Anis dan Kaluge. 2015. Pengaruh Beberapa Variabel Makroekonomi dan Indeks Pasar Modal Dunia terhadap Pergerakan Indeks Harga Saham Gabungan (IHSG) di BEI. Artikel. Fakultas Ekonomi dan Bisnis. Universitas Brawijaya. Malang.

[4] Kewal, Suramaya Suci. 2012. Pengaruh Inflasi, Suku Bunga, Kurs dan Pertumbuhan PDB Terhadap Indeks Harga Saham Gabungan. Jurnal Economia, 8(1): 67-80.

[5] Husnul, H. M; Hidayat, R. R; Sulasmiyati, S. (2017). Analisis pengaruh inflasi, kurs (IDR/USD), Produk Domestik Bruto dan harga emas dunia terhadap Indeks Harga Saham Gabungan. Jurnal Administrasi Bisnis, 53 (1): 66-74.

[6] Mamahit, Rina R; M. Tumbel, Tinneke; V. Mangindaan, Joanne. 2019 Pengaruh Variabel Makroekonomi Terhadap Indeks Harga Saham Gabungan (Studi pada Indeks Harga Saham Gabungan di Bursa Efek Indonesia Periode 2014-2018). Jurnal Administrasi Bisnis Vol. 8. No 2, 2019.

[7] Nancy Megawati \& M. Noor Salim. 2018. Pengaruh Variabel Makroekonomi Terhadap Indeks Harga Saham Gabungan (IHSG). Media Ekonomi. Vol. 26 No. 1 April 2018: 47-54.

[8] Triyono, David; Indarto; Santoso, Aprih. 2016. Analisis Pengaruh Indeks Harga Saham Asing Dan Variabel Makroekonomi Indonesia Terhadap Indeks Harga Saham Gabungan (IHSG) Di Bursa Efek 
Indonesia (Periode Januari 2013 - Agustus 2015). Jurnal Riset Ekonomi dan Bisnis 9 (22): 20 - 39.

[9] Astuti, Rini; Lapian, Joyce; Van Rate, Paulina. 2016. Pengaruh Faktor Makro Ekonomi terhadap Indeks Harga Saham Gabungan (IHSG) di Bursa Efek Indonesia. Jurnal Berkala Ilmiah Efisiensi, 16(2):399-406.

[10] Spence, Michael. 1973. Job Market Signaling. The Quarterly Journal of Economics, Vol. 87, No. 3. (Aug. 1973), pp. 355-374.

[11] Brigham, Eugene F. dan Houston, Joel F. 2011. Dasar-Dasar Manajemen Keuangan Terjemahan. Edisi 10. Jakarta: Salemba Empat.

[12] Bodie, Kane, \& Marcus. (2014). Investment. Tenth Edition. New York: McGraw-Hill Education.

[13] Ang, Robert. 2012, Buku Pintar Pasar Modal Indonesia (The Intelligent Guide to Indonesian Capital Market). Edisi Pertama. Mediasoft Indonesia. Jakarta.

[14] Bloomberg. 2020. Pergerakan IHSG periode 2010-2020. 1 Oktober 2020. Diakses dari PC Bloomberg.

[15] R Safiroh Febrina, Sumiati \& Kusuma Ratnawati. 2018. Pengaruh Variabel Makroekonomi Dan Harga Saham Asing Terhadap Indeks Harga Saham Gabungan. Jurnal Bisnis dan Manajemen Vol. 5 No.1, Januari 2018, p 118-126.

[16] Yu Hsing. 2011. Impacts of Macroeconomic Variables On The Stock Market In Bulgaria And Policy Implications. Journal of Economics and Business Volume XIV - 2011, No 2 (41-53)

[17] Tarika Singh, Seema Mehta, dan M. S. Varsha. 2011. Macroeconomic factors and stock returns: Evidence from Taiwan. Journal of Economics and International Finance Vol. 2(4), pp.217-227, April 2011.

[18] Ahmed Imran Hunjra, Muhammad Irfan Chani, Muhammad Shahzad. 2014. The Impact of Macroeconomic Variables on Stock Prices in Pakistan. International Journal of Economics and Empirical Research. 2014, 2(1), 13-21.

[19] Krishna Reddy Chittedi. 2015. Macroeconomic Variables impact on Stock Prices in a BRIC Stock Markets: An Empirical Analysis. Chittedi, J Stock Forex Trad 2015, 4:2. International Journal of Financial Studies 2019.

[20] Francisco Jareño dan Loredana Negrut. 2016.US Stock Market and Macroeconomic Factors. The Journal of Applied Business Research January February 2016. Volume 32, Number 1.

[21] Giri A. K. Dan Joshi Pooja. 2017. The Impact of Macroeconomic Indicators on Indian Stock Prices: An Empirical Analysis. Studies in Business and Economics no. 12(1)/2017.

[22] Putong, I. (2013). Economics :Pengantar Mikro dan Makro (Edisi 4). mitra wacana media.

[23] Moh Maulidi Syarif dan Nadia Asandimitra. 2015. Pengaruh Indikator Makro Ekonomi Dan Faktor Global Terhadap Indeks Harga Saham Gabungan (IHSG). Jurnal Studi Manajemen, Vol.9, No 2, Oktober 2015: 142-156.

[24] I Putu Wahyu Putra Asmara dan Anak Agung Gede Suarjaya. 2018. Pengaruh Variabel Makro Ekonomi Terhadap Indeks Harga Saham Gabungan. E-Jurnal Manajemen Unud 7 (3), 1397-1425

[25] Ulis Sa'adah Suhadak. 2019. Pengaruh Makroekonomi Terhadap Kinerja Indeks Harga Saham Gabungan (Ihsg) Dan Government Bonds (Studi pada Negara Indonesia Tahun 2015-2017). Jurnal Administrasi Bisnis (JAB) Vol 1 Agustus 2019: 151-159. 